\title{
STAT3 Inhibitor OPB-31121
}

National Cancer Institute

\section{Source}

National Cancer Institute. STAT3 Inhibitor OPB-31121. NCI Thesaurus. Code C90588.

An orally bioavailable inhibitor of signal transducer and activator of transcription 3

(STAT3), with potential antineoplastic activity. OPB-31121 inhibits the phosphorylation of STAT3, which prevents binding of STAT 3 to DNA sequences on a variety of STAT3responsive promoters and may result in the inhibition of STAT3-mediated transcription and, potentially, the inhibition of tumor cell proliferation. STAT3 is constitutively activated in a variety of cancers, contributing to the loss of cell growth control and neoplastic transformation. 